\title{
STUDENT RESEARCH: ACQUIRING KNOWLEDGE ABOUT THE NATURE AND PROCESS OF SCIENCE
}

\author{
Todar Lakhvich \\ Belarusian State Medical University, Republic of Belarus
}

In April of 2017, I was working with the team of FEBS (Federation of European Biochemical Societies) Education Ambassadors from different European countries and Education Committee members in Université Paris Descartes. This was a significant event, involving FEBS Constituent Societies, to create a platform at the Europen level to brainstorm on educational issues across Europe. The discussions focused on what would be done in order to meet the mission and vision of FEBS on educational issues $\mathbb{Q}$ to promote education throughout Europe. Along with the other very important issues (curriculum, inventory of key skills, good practice, etc.) the working group on learning resources has elaborated short and long term objectives to formation of an appropriate learning database in the field of Biochemistry and Molecular Biology education. The participants discussed a lot about the importance of inquiry based approach which includes in particular the conduction, evaluation and presentation of Student Research.

Plato was the first who defined the education being the way to comprehend the whole of life, and to be a preparation for another in which education begins again. It coincides with the scientific paradigm in which the research method affords to study the facts, to confirm the results of previous findings, to solve different problems and to develop a theory.

The traditional education is based mainly on mastery of content, neglecting the training of inquiring attitudes. Such system of education is teacher-centered, the students getting the information from a teacher about the known facts, often "the only correct answer" is proposed. Learning is accomplished through words, symbols and images (which are also the linguistic components) rather than through active involvement of students in the processes which regard the situations for their future social and professional environment. Systematic product- and/or discipline-oriented, rule-based instructive teaching and learning provide the acquisition of basic knowledge in primary, mostly in secondary and high schools, and still plays an important role in University education. Some educators persist such a type of education supports the traditions and prepares students for the next (school) grade level. Even when it's partially true, in-school success means less than a system helping a student learn to learn throughout life.

In contrary, process-oriented, self-directed, creative and interdisciplinary learning which is referred to constructivist paradigms mostly used in academic education, still elements of it are involved in secondary and high school practice. The inquiry technology is aimed on using and learning content as a means to develop information-processing and problem-solving skills. Such approach is student centred, they are being the participants of the projects.

Though inquiry can be done even in lectures, the best results are distinguished in the laboratory or group work, and in particular within carrying out the student research.

There are a lot of investigations done about the student research, which include both fundamental works 
ISSN 1648-3898/Print/

ISSN 2538-7138/Online/

(e.g. Peters, 2012; Strayhorn, 2013) and more focused on definite fields of knowledge, e.g. few recent investigations on Student Research in the field of Biomedical Sciences and Geography (Amgad, 2015; Ballamingie, 2013; Slack, 2016).

In Universities students within the Master and PhD programs carry out the real scientific research. The lower level of education the less research component is included in the academic process. But only the continuing education with the similar objectives, procedures and technologies on every educational and career level creates the ideal environment for the formation of individual adaptive competence in learning and training. In this context, the introduction of the approaches used at higher levels of education (e.g. University technologies for High School, or research methodology for University training) in practice may solve the problem of psychological, socio-cultural and professional adaptation of students at the further stages of training and life social activity. In this context the Student Research models the real scientific research. It provides such an organization of the educational process, in which at each stage, students acquire relevant knowledge, training and skills through the assimilation of the principles of scientific research.

Student Research is often wrongly associated with laboratory studies. However, on the one hand, not every laboratory experiment is a study, on the other - similar to originally scientific research, student research based on the same procedure and includes formulation of research problem, work with literature, design of experiments (formulating of the aim, conceptual framework and specific questions of research, choice of methodology and procedure), conducting the experiment itself, data collection followed by their verifying, analyzing and interpreting, summarizing and finally presenting the results (publishing and conference activity). Most universities provide the equipment and resources for real scientific research, which is problematic for high and secondary school. But in both cases students are limited in time, being involved in different forms of academic activity according to the curriculum. This makes the idea of the "real scientific research" illusive for most of the students. To resolve this problem, an educator must organize the Student Research in such a way to take in account all procedural, psychological and didactic aspects of the educational process (Bratennikova, Vasilevskaja, \& Lahvich, 2001):

- To use only a few elements of research technology: the higher level of education the closest research structure of scientific research;

- The experiments do not necessarily have to be absolutely innovative, the key point is a subjective novelty of the research for the students;

- The research primarily pursues educational and training rather than utilitarian objectives;

- Mostly modelling, rather than useless transferring the real problem situation of scientific research in student research, with the exception of expensive equipment and materials;

- Taking into account the psycho-physiological characteristics of students in a particular age group.

The academic process at medical Universities (Schools) is traditionally practically oriented and includes only a few elements of scientific technologies. We tried to introduce the more student researches for undergraduate students ( $1^{\text {st }}-4^{\text {th }}$ grades) before they would be proposed to enter master and/or PhD program instead of Medical internship. We have proposed students (mostly from School of Pharmacy) the projects concerning the search and primary investigation of biological activity of organic substances as potential pharmaceutical drugs. Molecular docking was the key element of the research project (Kitchen, 2004). The research included also the literary review and drug analysis (Journals, drug databases), the choice of the possible substrates (protein databases), the evaluation in silico the model based on a set of substances synthesized earlier and tested in vivo on biological activity, design of new drug-candidates and the assessment of their activity in silico. The results obtained were valid and correlated with the data from previous scientific researches and were presented in student conferences and, finally, published. Student research motivates students to study professionally oriented topics, trains their skill in the field of pharmaceutical chemistry and molecular biology, as well as helping us to find the candidates for entering the Master and PhD programs. And for sure the models obtained are both beautiful and useful (Lakhvich, 2010)

The experience can be broadened easily to High School. At High School students should acquire not only specific competencies (i.e. knowledge in specific topics, such as Biology, Chemistry, Mathematics, etc.) but also nonspecific competencies in life and social skills, like team working, self-management, responsibility (in terms of attention, critical participation, punctuality, etc.) It's also important because most undergraduate students will soon access the Universities. Collaboration between University and High School included the formation of groups which consisted of University professor and few High School teachers and University 
and High School students, which are under supervision of University professor and University student work on scientific topics. In such a group, high school teachers play different roles. On the one hand, he/she again, acquires as a student the new knowledge. On the other hand, the teacher professionally directs the efforts of school students using their skills in didactics and social management. In such groups we observe the real exchange of competencies, professional and life experiences. It looks like phase-transfer catalysis in chemistry where a specific catalyst having fragments with different functionalities (i.e. hydrophobic and hydrophilic fragments in quaternary ammonium salts) accelerate the reaction by the migration of a reactant from one phase into another.

Phase-transfer catalysis give rise to faster reactions, better yields, fewer byproducts, less expensive and/ or dangerous reagents and solvents. Just that is what we may refer to environmentally friendly chemistry. Student Research and educational research groups also give rise to social integration and faster professional growth of teachers and professors, as well as better understanding and milder adaptation of students. School students study topics and acquire skills, from University level, being prepared for University education. University students develop their skills and sustain knowledge by supervising and teaching school students, adapting for future professional activity (it can include teaching, science, working in an industry which also requires the competencies of supervising, teaching and team work).

The definition of research can be expressed in a few words which are straightforward and absolutely inclusive: systematic inquiry that is made public and exposed to collective criticism (Stenhouse, in Rudduck, 1985, p. 120). Thus, the student research may include the same topics and follow the same requirements as the "normal" scientific research. Master theses' requirements usually follow the regulations for scientific papers. There are few examples of Nobel Prize winners who conducted their triumph investigations within their Master programs. But the rest of students will meet the real scientific research later. Most of them will join practical projects in their professional activity. But their involvement in student researches will help them to adapt socially and professionally in future life.

Student researches are supported through the curricular flexibility, advanced degree programs, tuition policy, financial bonuses, and by the special recognition of students who carry out research. Similar to real scientific research student projects "seeking through the methodological process to add one's own body of knowledge and, hopefully, to that of others, by the discovery of nontrivial facts and insights" (Peters, 2012, P.8). And all those aspects were discussed at the meeting of FEBS Education Ambassadors and members of the FEBS Education Committee in Université Paris Descartes in April of 2017. For fast publication of the results from researches FEBS Open Bio (online-only open access journal for the rapid publication of research articles in molecular and cellular life sciences in both health and disease) has created Education Section. But the educational researches in the field must be published in specialized journals. Journal of Baltic Science Education kindly invites you to contribute to the result of scientific research which study all the didactic, social and psychological aspects of Student Research in the field of Science and Education. For sure, we are waiting the authors would follow both all the requirements of scientific research in the field of Science Education and the Journal policy.

\section{References}

Amgad, M., Tsui, M. M. K., Liptrott, S. J., Shash, E. (2015). Medical student research: An integrated mixed-methods systematic review and meta-analysis. PLoS one, 10 (6), e0127470.

Ballamingie, P., \& Tudin, S. (2013). Publishing graduate student research in geography: The fundamentals. Journal of Geography in Higher Education, 37 (2), 304-314.

Bratennikova, A. N., Vasilevskaja, E. I., \& Lahvich, F. F. (2001). Obuchajushhe-issledovatel'skij princip kak sredstvo realizacii preemstvennosti pri formirovanii adaptivnyh kompetencij specialist [Teaching-research principle as a means of implementing continuity in the formation of adaptive competences of a specialist]. In, Adaptacija k professional'noj dejatel'nosti kak psihologo-pedagogicheskaja problema: Mat. mezhd. Konf [Adaptation to professional activity as a psychological and pedagogical problem]. Baranovichi: BGVPK, 29-33.

Kitchen, D. B., Decornez, H., Furr, J. R., Bajorath, J. (2004). Docking and scoring in virtual screening for drug discovery: Methods and applications. Nature Reviews Drug Discovery, 3 (11), 935-949.

Lakhvich, T. (2010). Beautylity of chemistry visualization: Whether useful can be aesthetic. Problems of Education in the 21st Century, 19, 46-50. 
ISSN 1648-3898/Print/

ISSN 2538-7138/Online/

Peters, M. J., Howard, K., \& Sharp, M. J. A. (2012). The management of a student research project. Gower Publishing, Ltd..

Rudduck, J. \& Hopkins, D. (1985). Research as a basis for teaching: Readings from the work of Lawrence Stenhouse. London: Heinemann.

Slack, M. K., Martin, J., Worede, L., \& Islam, S. (2016). A systematic review of extramural presentations and publications from pharmacy student research programs. American Journal of Pharmaceutical Education, 80 (6), 100

Strayhorn, T. L. (2013). Theoretical frameworks in college student research. University Press of America.

Peters, M. J., Howard, K., \& Sharp, M. J. A. (2012). The management of a student research project. Gower Publishing, Ltd.

Received: November 11, 2017

Accepted: December 18, 2017

Todar Lakhvich

PhD., Associate Professor, Department of Bioorganic Chemistry,

Belarusian State Medical University, Dzerzhinski Ave., 83, 220116

Minsk, Republic of Belarus.

E-mail: lakhvichtt@bsmu.by

Website: https://eng.bsmu.by/ 